\title{
RESPONSE OF Cattleya forbesii ORCHID TO INCREASING SILICON CONCENTRATIONS IN VITRO
}

\author{
RONAN CARLOS COLOMBO ${ }^{2 *}$, VANESSA FAVETTA ${ }^{2}$, RICARDO TADEU DE FARIA ${ }^{2}$, FELIPE ARANHA DE \\ ANDRADE $^{2}$, VANDERLI MARINO MELEM ${ }^{3}$
}

\begin{abstract}
Addition of Silicon (Si) to culture media has been shown to improve the development of seedlings grown in vitro, and to reduce losses during the acclimatization phase. The objective of this study was to evaluate the in vitro growth of Cattleya forbesii (Orchidaceae) in MS medium containing five different concentrations of $\mathrm{SiO}_{2}\left(0.0,0.5,1.0,1.5\right.$, and $\left.2.0 \mathrm{~g} \cdot \mathrm{L}^{-1}\right)$. At day 200 , the following variables were measured: number of roots, average length of the root system, leaf area, number of leaves and shoots, shoot height, fresh and dry masses of roots and shoots, water content of roots and shoots, and $\mathrm{pH}$ of the culture medium. Most variables decreased as the concentration of $\mathrm{Si}$ increased, reducing the in vitro vegetative growth of $C$. forbesii. Accumulation of Si in leaf tissues was detected by scanning electron microscopy, confirming uptake by plants. The Si source and concentrations tested showed no beneficial effect on in vitro growth of $C$. forbesii.
\end{abstract}

Keywords: Micropropagation, Culture medium, Amorphous silica.

\section{SILÍCIO NO DESENVOLVIMENTO IN VITRO DA ORQUÍDEA Cattleya forbesii}

RESUMO - A adição de silício ( $\mathrm{Si}$ ) aos meios de cultura tem apontado melhor desenvolvimento das plântulas cultivadas in vitro e redução das perdas durante a fase de aclimatização. Objetivou-se avaliar cinco concentrações de $\mathrm{SiO}_{2}\left(0,0 ; 0,5 ; 1,0 ; 1,5\right.$ e $\left.2,0 \mathrm{~g} \cdot \mathrm{L}^{-1}\right)$ em meio de cultura MS sobre o crescimento in vitro da orquídea Cattleya forbesii. Aos 200 dias, avaliou-se as variáveis: número de raízes, comprimento médio do sistema radicular, área foliar, número de folhas e de brotos, altura da parte aérea, massa fresca e seca de raízes e de parte aérea, conteúdo de água das raízes e da parte aérea, e pH final dos meios de cultura. Para a maioria das variáveis avaliadas observou-se decréscimo em função do aumento da concentração de $\mathrm{Si}$, reduzindo o desenvolvimento vegetativo in vitro da $C$. forbesii. Além disso, detectou-se acúmulo de Si nos tecidos foliares por meio da microscopia eletrônica de varredura, confirmando a absorção deste pelas plântulas. Para o crescimento in vitro da espécie estudada, a fonte e concentrações de Si testadas, não apresentaram efeito benéfico.

Palavras-chave: Micropropagação. Meio de cultura. Sílica amorfa.

\footnotetext{
${ }^{*}$ Corresponding Author

${ }^{1}$ Received for publication in 06/03/2014; accepted in 09/28/2015.

Senior Research Project for specialization in Statistics with Emphasis on Quantitative Research of the first author.

${ }^{2}$ Center of Agrarian Science, Department of Agronomy, Universidade Estadual de Londrina, Londrina, PR, Brazil; ronancolombo@yahoo.com.br, vanfavetta@hotmail.com, faria@uel.br, felipearanhaa@hotmail.com.

${ }^{3}$ Center of Exact Sciences, Department of Statistic, Universidade Estadual de Londrina, Londrina-PR, Brazil; vanderli@uel.br.
} 


\section{INTRODUCTION}

Cattleya forbesii Lindl. (Orchidaceae), native to the state of Paraná, Brazil, grows to approximately $20 \mathrm{~cm}$ tall, and is bifoliate and predominantly epiphytic. Its flower stalks arise from the apex of fully developed pseudobulbs and give rise to two to four yellowish-brown flowers with a pink and yellow -gold labellum, of ample dimensions and durability (flowers last for 15-20 days). Blossoming generally occurs in the months of December and January (CARDOSO; ISRAEL, 2005).

In vitro culture has been an excellent alternative for the propagation of Orchidaceae, as it presents advantages over other conventional propagation methods, (CAMPOS, 2004) such as division of adult plants or cutting of pseudobulbs. The MS medium (MURASHIGHE and SKOOG, 1962) used for the micropropagation of orchids has been used with some modifications, such as the reduction of nutrient concentrations and/or the addition of other components (FARIA et al., 2012). Some modifications stand out the most, e.g., the use of sodium and potassium silicate for orchids of the genus Cattleya (SOARES et al., 2011).

Supplementation of culture media with silicon (Si) may benefit plants propagated in vitro, increasing the hemicellulose and lignin content and thereby increasing cell wall rigidity (CAMARGO et al., 2007). According to Epstein (2001), the use of a Si source can increase both the levels of chlorophyll in leaves and the tolerance of plants to environmental stresses, which are often a problem in the acclimatization of micropropagated seedlings.

In addition to silicates, other sources of $\mathrm{Si}$ exist, such as amorphous silicas extracted from diatom fossils. According to Hildebrand (2003), diatoms are the main producers of biogenic silica, with respect to both the amount of synthesized material and the variety of structures. However, to our knowledge, no studies reporting the addition of this Si source in culture media, bearing in mind its influence on seedling growth and acclimatization, can be found in the literature.

Thus, the objective of the present study was to evaluate the effect of amorphous silica added to MS medium on in vitro growth of $C$. forbesii orchid.

\section{MATERIAL AND METHODS}

C. forbesii seedlings originated from seeds germinated in vitro, in MS medium containing half the standard macronutrient concentration ( $1 / 2 \mathrm{MS})$, were selected 90 days after sowing and subcultured in the same medium, with the addition of a commercial product containing $94.6 \% \mathrm{SiO}_{2}$ in five concentrations $\left(0,0.5,1.0,1.5\right.$, and $\left.2.0 \mathrm{~g} \cdot \mathrm{L}^{-1}\right)$. The base medium was composed of $30 \mathrm{~g} \cdot \mathrm{L}^{-1}$ sucrose, $1 \mathrm{~g} \cdot \mathrm{L}^{-1}$ activated carbon, and $10 \mathrm{~g} \cdot \mathrm{L}^{-1}$ agar; the $\mathrm{pH}$ was adjusted to $5.8 \pm 0.2$ before the addition of agar. $50 \mathrm{~mL}$ of culture medium was added to $250-\mathrm{mL}$ glass bottles, then autoclaved at $121^{\circ} \mathrm{C}$ and $100 \mathrm{kPa}$ for $25 \mathrm{~min}$. After inoculation of the seedlings into the culture medium, the bottles were kept in a growth chamber at a temperature of $25 \pm 2{ }^{\circ} \mathrm{C}$ under a 16 -h photoperiod at $25 \mu \mathrm{mol} \cdot \mathrm{m}^{-2} \cdot \mathrm{s}^{-1}$ photosynthetic photon flux density (PPFD).

A completely randomized design was used for the experiment; five treatments of 10 replicates each were set up, wherein each replicate consisted of five seedlings.

At day 200, the following variables were evaluated: number of roots; average length of the root system $(\mathrm{cm})$; fresh root mass $(\mathrm{g})$; dry root mass $(\mathrm{g})$; root water content $(\%)$; leaf area $\left(\mathrm{mm}^{2}\right)$, using ImageJ software; number of leaves; number of shoots; shoot height $(\mathrm{cm})$; fresh shoot mass $(\mathrm{g})$; dry shoot mass (g); shoot water content $(\%)$; and the final $\mathrm{pH}$ of the culture media.

The variables were subjected to an analysis of variance (ANOVA) and linear regression, using the statistical software Sisvar ${ }^{\circledR}$ (FERREIRA, 2011). Data on the number of leaves, number of shoots, and number of roots were transformed by the function $\sqrt{x}_{\mathrm{x}}$ +1 .

Deposition of Si in the leaves was visualized by scanning electron microscopy (SEM). For this ultrastructural analysis, the penultimate fully expanded leaf from two seedlings per treatment was used as control. The leaves were cut in the middle third section, and the segments obtained were placed in formalin-acetic acid (FAA) fixative solution containing 5\% formaldehyde, $90 \%$ ethyl alcohol $(70 \% \mathrm{abv})$, and $5 \%$ acetic acid. The leaves were immersed in FAA for $24 \mathrm{~h}$ at $25^{\circ} \mathrm{C}$.

In order to obtain the images, the fixed materials were dehydrated in a graded ethanol series $\left(70,80,90\right.$, and $100 \%$ abv) and dried in $\mathrm{CO}_{2}(\mathrm{Bal}$ Tec CPD 030). Next, the samples were affixed to microscopy sample stubs with the abaxial side facing upward and coated with carbon, using the Bal-Tec SCD 050 Sputter Coater. In order to detect $\mathrm{Si}$, the samples were analyzed by energy dispersive spectroscopy (EDS; Oxford), using INCA software coupled to an FEI Quanta 200 scanning electron microscope.

\section{RESULTS AND DISCUSSION}

As the concentration of $\mathrm{Si}$ increased in the culture media, decreases in the number of roots and average length of the root systems were observed (Figure 1A and B). Soares et al. (2011), studying the addition of sodion and potassium silicates to Knudson $\mathrm{C}$ culture medium, found opposite results on in vitro development of Cattleya loddigesii; however, this finding may be attributed to the extra addition of sodion and potassium in the culture medium due to the choice of silicates. 


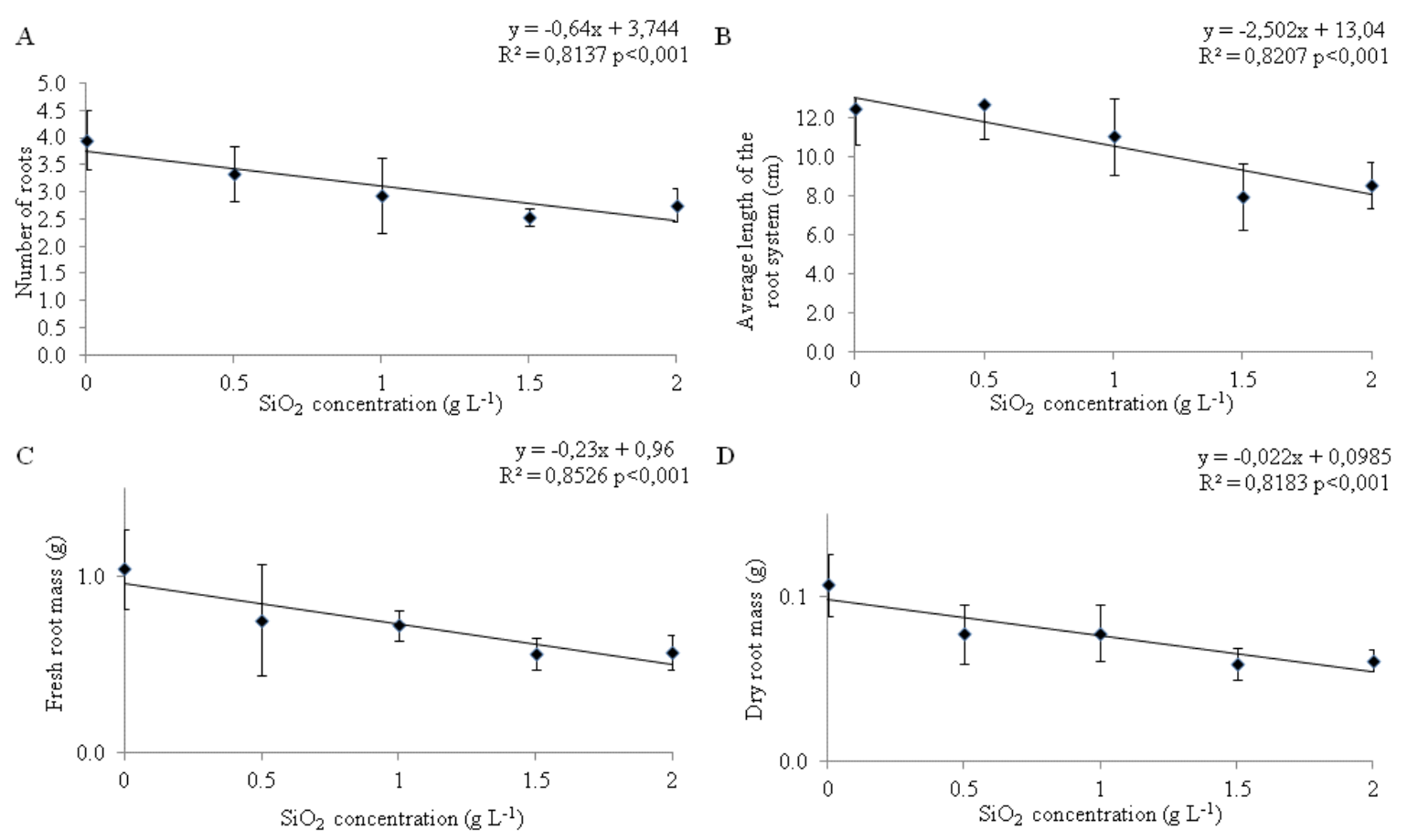

Figure 1. Characteristics of Cattleya forbesii seedlings subcultured in vitro at different Si concentrations: number of roots (A), average length of the root system (B), fresh (C) and dry (D) root masses.

Asmar et al. (2011), when studying the effect of sodium, potassium, and calcium silicates added to an MS culture medium for the micropropagation of banana variety 'Maçã', observed no statistical differences in the length of the roots or their fresh and dry masses when compared to the control medium (MS medium with no silicate addition). However, in the present study, root fresh and dry masses decreased in response to increased concentrations of Si (Figure 1C and D), accompanied by a decrease in the number of roots and average length of the root system. In the $2 \mathrm{~g} \cdot \mathrm{L}^{-1} \mathrm{Si}$ concentration treatment, a reduction of approximately $50 \%$ in root fresh and dry masses was observed when compared to the treatment without $\mathrm{Si}$.

Since the roots function in nourishing the shoots, a lower root system growth rate typically reflects negatively on the shoot growth rate. This can be seen in Figure 2, wherein reduced shoot development is correlated with $\mathrm{Si}$ concentration.

The number of leaves on the seedlings did not fit the linear regression models tested, indicating that Si concentration does not have a significant effect on leaf number. This finding is consistent with the results of Asmar et al. (2011), who observed no statistical differences in the number of leaves of seedlings of the banana variety 'Maçã' grown in MS medium as compared to MS medium containing sodium, potassium and calcium silicates.

However, in a study conducted with $C$. loddigesii cultured in Knudson $\mathrm{C}$ medium, the highest number of leaves was obtained with the addition of $20 \mathrm{mg} \cdot \mathrm{L}^{-1}$ of sodium silicate and 20 $\mathrm{mL} \cdot \mathrm{L}^{-1}$ of potassium silicate (SOARES et al., 2011). Similar results were observed in the leaves of blackberry (Rubus spp.) cultivated in vitro; the number of leaves increased as incremental concentrations of $\mathrm{K}$ were added to the modified MS culture medium, and the highest number of leaves was observed at the concentration of $1 \mathrm{~g} \cdot \mathrm{L}^{-1} \mathrm{KCl}$. However, these authors do not attribute this effect only to the $\mathrm{Si}$, considering that $\mathrm{K}$ was added to these media owing to the use of silicate or $\mathrm{KCl}$ (VILLA et al., 2008). The regulation of osmotic potential in plant cells is regulated by $\mathrm{K}$, which also activates enzymes involved in respiration and photosynthesis (TAIZ; ZEIGER, 2009). Therefore, it is possible to attribute increased leaf growth observed in these studies to $\mathrm{K}$ rather than $\mathrm{Si}$.

Shoot fresh and dry masses also decreased linearly as $\mathrm{Si}$ concentration increased, indicating smaller seedlings with fewer reserves, which may become a problem in the acclimatization phase. Soares et al. (2011) found that the fresh mass of $C$. loddigesii seedlings showed no significant changes when grown in Knudson C medium with and without the addition of different concentrations of potassium silicate. In the presence of up to $10 \mathrm{mg} \cdot \mathrm{L}^{-1}$ sodium silicate, a decrease in shoot mass was observed. Braga et al. (2009) observed no statistical differences for fresh and dry shoot masses in 'Oso Grande' strawberry seedlings grown in MS medium with and without addition of sodium and potassium silicate. 

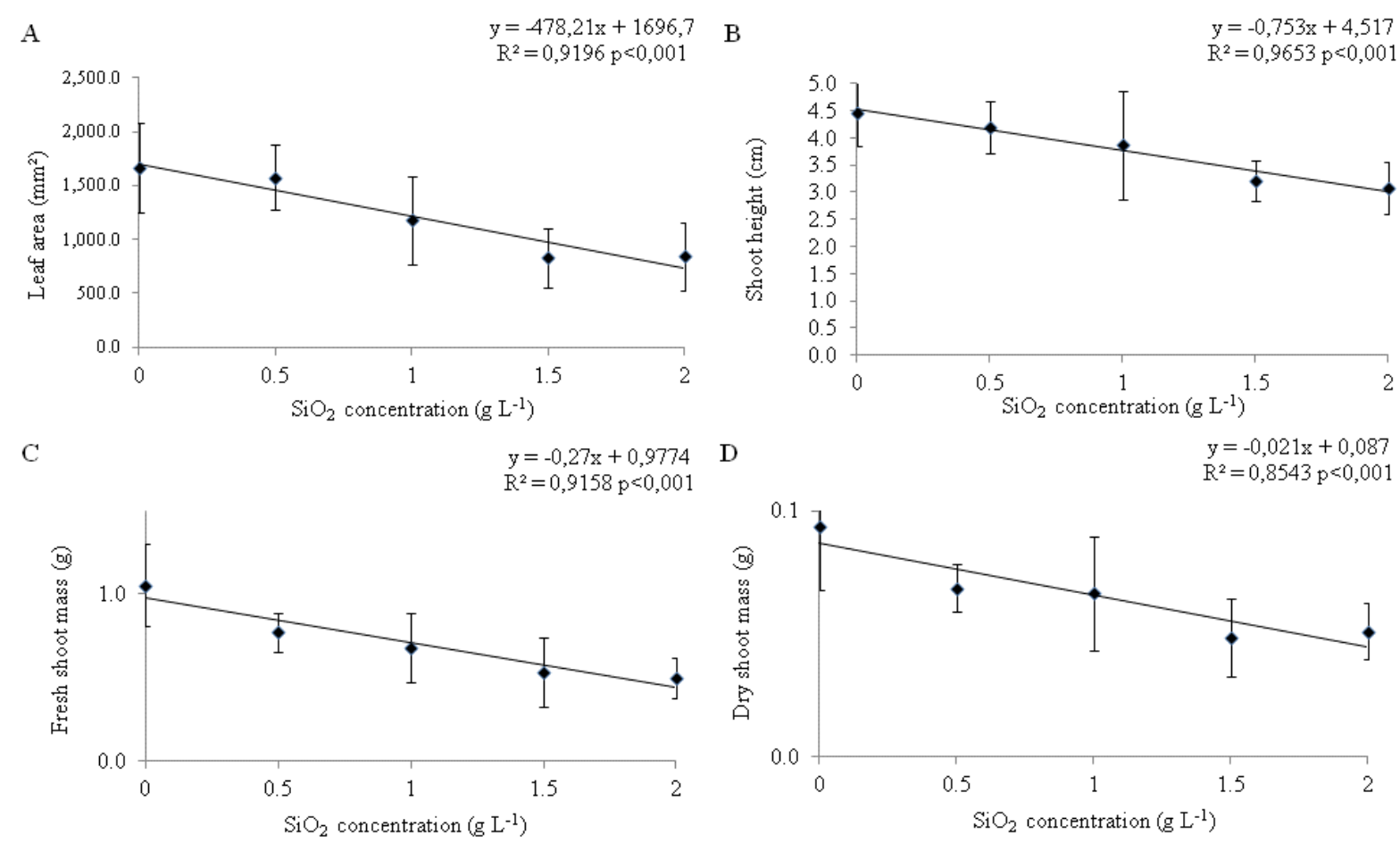

Figure 2. Characteristics of Cattleya forbesii seedlings subcultured in vitro at different Si concentrations: leaf area (A), shoot height (B), and fresh (C) and dry (D) shoot masses.

No statistical differences were observed between treatments for the water content of the shoots. However, as the concentration of $\mathrm{Si}$ increased, a small decline in water content was observed; the water content was $91 \%$ in the treatment without addition of $\mathrm{Si}$, and $89 \%$ in the treatment containing a concentration of $2 \mathrm{~g} \cdot \mathrm{L}^{-1} \mathrm{Si}$. Braga et al. (2009) observed that the presence of sodium and calcium silicate in MS medium significantly reduced the water content of 'Oso Grande' strawberry shoots compared to the control medium, MS medium without added silicates. These treatments are thus associated with higher accumulation of dry matter compared to fresh weight.

No significant effect of Si concentration was observed on the number of shoots produced, and thus, no curve that fits this variable was obtained. Sprouting in this case might be caused by some stress-related factor as a result of the concentrations of Si used, considering that in treatments wherein $\mathrm{Si}$ was present, a higher number of shoots was observed. Soares et al. (2011) observed that by adding incremental concentrations of $\mathrm{Na}$ silicate to Knudson $\mathrm{C}$ medium, an increase in the number of shoots of $C$. loddigesii was observed.

Figure 3 displays the average $\mathrm{pH}$ values between the treatments at the end of the experimental period. It was verified that in the treatments where $\mathrm{Si}$ was added, the $\mathrm{pH}$ was higher than in the control. Lower $\mathrm{pH}$ values may be related to the absorption of cations from the culture medium by the seedlings, and the release of $\mathrm{H}^{+}$ions from the roots to the medium as a result of the electrogenic protonpumping activity of $\mathrm{H}^{+}$-ATPase (TAIZ; ZEIGER, 2009; YI-YONG et al., 2011). Hence, greater development of the seedlings results in greater acidification of the media.

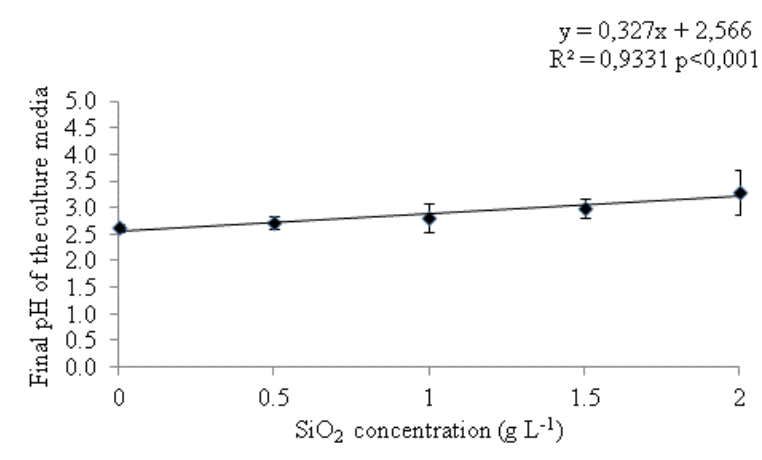

Figure 3. Culture media $\mathrm{pH}$ values 200 days after in vitro subcultivation of Cattleya forbesii seedlings as a function of Si concentration. 
Figures 4 and 5 display the ultrastructure of the abaxial surface of the leaf epidermis of $C$. forbesii, subcultured in the absence and presence of $\mathrm{Si}$. Accumulations of $\mathrm{Si}$ were observed in the

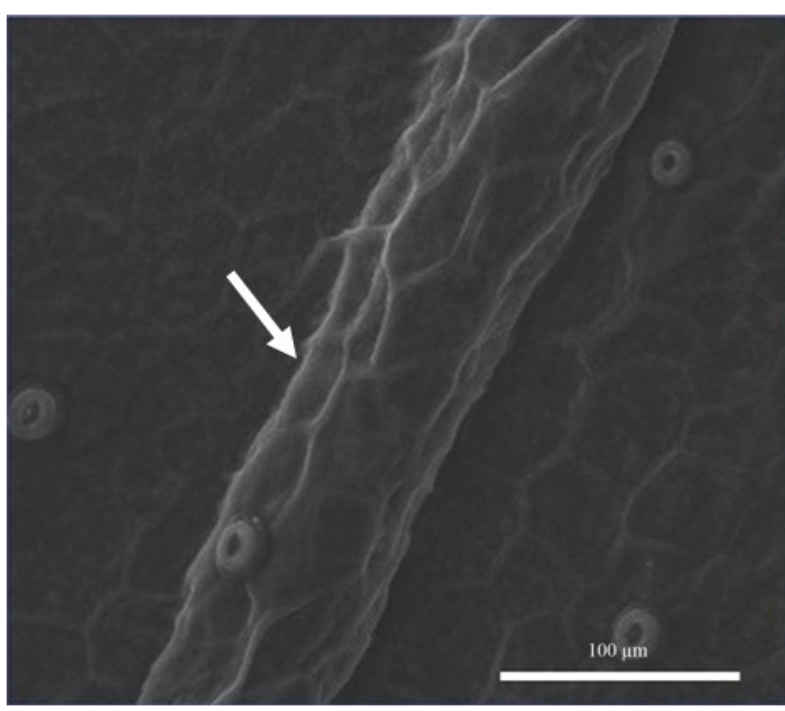

vicinity of the leaves' veins when the seedlings were treated with $\mathrm{Si}$ concentrations of $0.5,1.0,1.5$, and $2.0 \mathrm{~g} \cdot \mathrm{L}^{-1}$ (Figure 5).

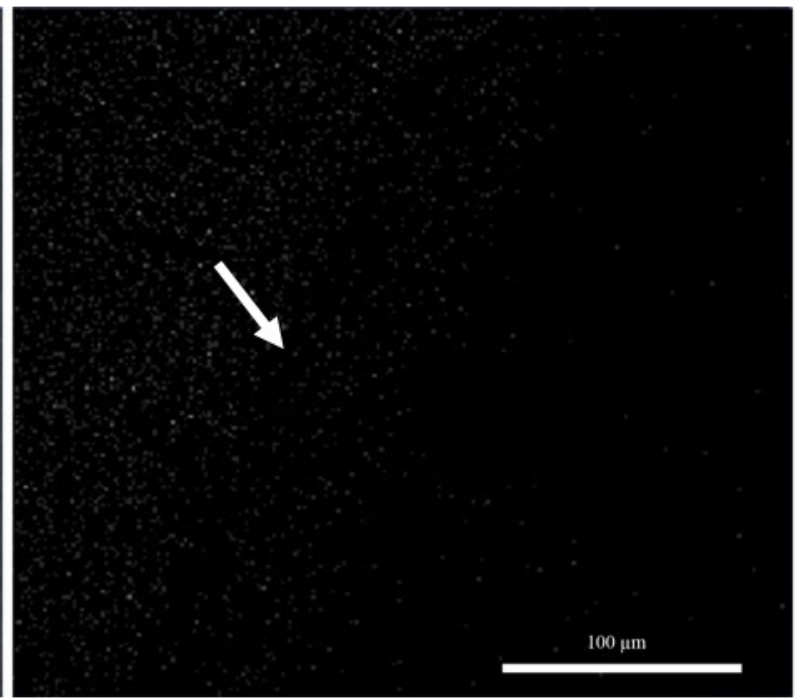

Figure 4. Scanning electron micrographs of the Cattleya forbesii leaf epidermis, subcultivated in vitro without addition of Si. Frontal view of the abaxial surface of the leaf blade (left). Si mapping (white dots) on the abaxial surface of the leaf blade (right). Arrow (venation).

The plants absorb Si preferentially in the form of monosilicic acid $\left(\mathrm{H}_{4} \mathrm{SiO}_{4}\right)$, and deposit it as $\mathrm{SiO}_{2}$ in the leaves' cell walls (EPSTEIN, 1999). The transport of $\mathrm{Si}$ from the root to the shoot occurs through the xylem, and it depends on the evapotranspiration rate (JONES; HANDRECK, 1965). Thus, water loss as a result of transpiration in the leaves leads to the formation of hydrated amorphous silica, particularly in epidermal cells of leaf tissues (ZANÃO Jr. et al., 2009). As a result, it is possible to better understand the deposition of $\mathrm{Si}$ in the regions comprising the leaf veins.

Further investigation regarding the deposition of $\mathrm{Si}$ in the leaves is still needed. However, the deposition of this element in the venous region may have obstructed the conducting vessels, hindering sap flow in the seedlings and negatively affecting its development, an effect that is amplified by increase in $\mathrm{Si}$ concentration.

It was not possible to identify the formation of silica bodies (stegmata) in the leaf tissue analyzed by SEM. However, the inexistence of such bodies cannot be confirmed, because in this analysis, only a sample of the middle third section of the penultimate fully expanded leaf was used. It is possible for fully formed stegmata to be found in the lower leaves. Zanenga-Godoy and Costa (2003), when studying the leaf anatomy of four species of the genus Cattle$y a$, observed silica deposition on the leaves forming silica bodies. Corroborating these findings, Dettke et al. (2007) also observed the formation of silica bodies in three species of the orchid genus Maxillaria.

Therefore, it is crucial to conduct more studies on the dynamics of $\mathrm{Si}$ in culture media and seedlings, as well as its influence on the seedlings' acclimatization process. Considering that the accumulation of Si occurs in the leaves, it is possible that this element is beneficial to the development of ex vitro seedlings. 


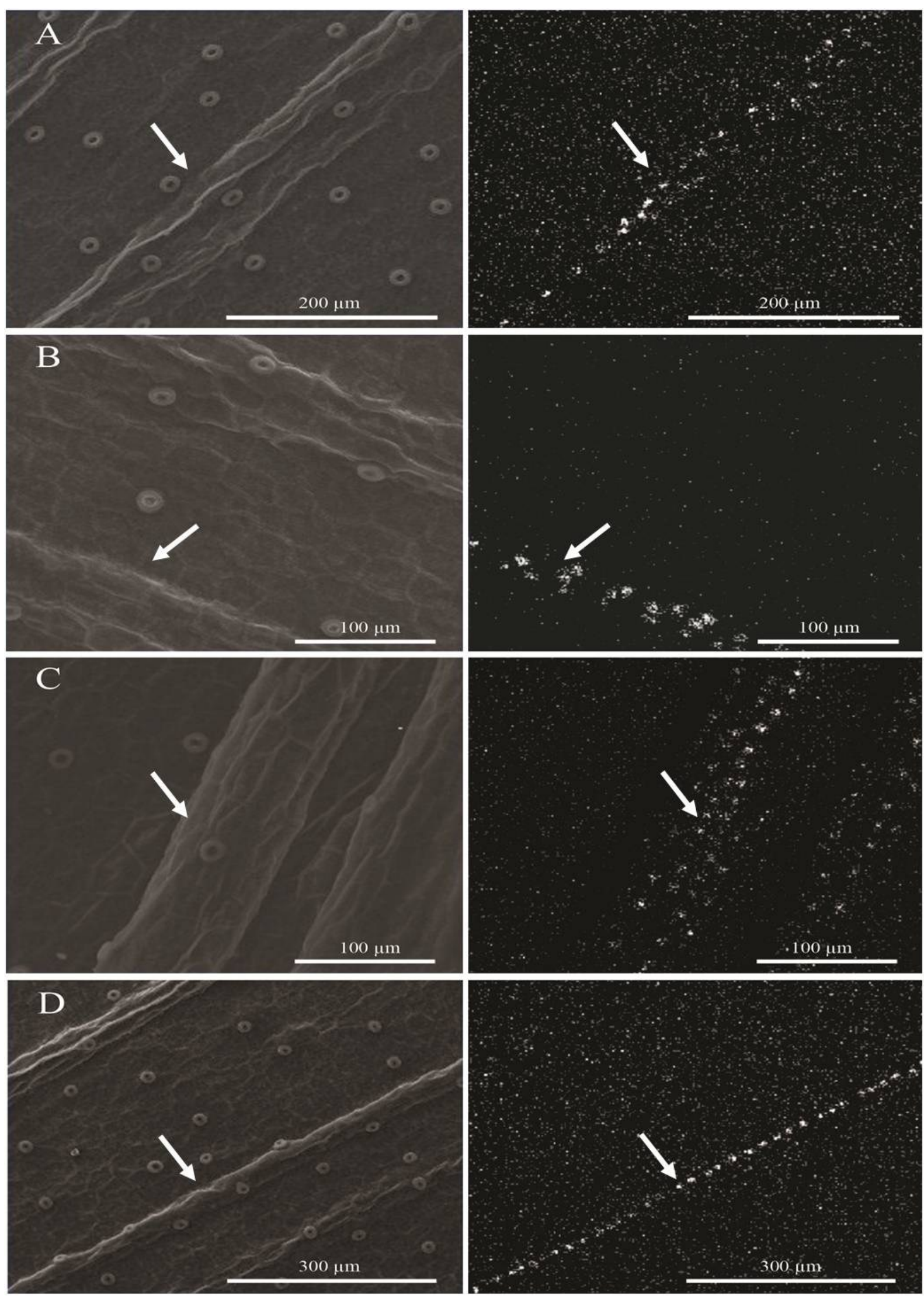

Figure 5. Scanning electron micrographs of the Cattleya forbesii leaf epidermis, subcultivated in vitro and submitted to Si concentrations of $0.5 \mathrm{~g} \cdot \mathrm{L}^{-1}(\mathrm{~A}) ; 1.0 \mathrm{~g} \cdot \mathrm{L}^{-1}(\mathrm{~B}) ; 1.5 \mathrm{~g} \cdot \mathrm{L}^{-1}(\mathrm{C})$ and $2.0 \mathrm{~g} \cdot \mathrm{L}^{-1}$ (D). Frontal view of the abaxial surface of the leaf blade (left image). Si mapping (white dots) on the abaxial surface of the leaf blade (right image). Arrow (venation). 


\section{CONCLUSION}

The source and concentrations of Si examined in this study reduce the growth of $C$. forbesii subcultivated in vitro. Based on SEM images and EDS analysis, $\mathrm{Si}$ accumulates in the leaves, depending on the concentration in the medium.

\section{ACKNOWLEDGEMENTS}

The authors thank the Brazilian Federal Agency for the Support and Evaluation of Graduate Education (Capes) and the National Council for Scientific and Technological Development (CNPq) for financial support.

\section{REFERENCES}

ASMAR, S. A. et al. Fontes de silício no desenvolvimento de plântulas de bananeira 'Maçã' micropropagadas. Ciência Rural, Santa Maria, v. 41, n. 7, p. 1127-1131, 2011.

BRAGA, F. T. et al. Características anatômicas de mudas de morangueiro micropropagadas com diferentes fontes de silício. Pesquisa Agropecuária Brasileira, Brasília, v. 44, n. 2, p .128-132, 2009.

CAMARGO, M. S.; KORNDÖRFER, G. H.; PEREIRA, H. S. Solubilidade do silício em solos: influência do calcário e ácido silícico aplicados. Bragantia, Campinas, v. 66, n. 4, p. 637-647, 2007.

CAMPOS, D. M. Cultura in vitro simplificada. O mundo das orquídeas, n. 36, São Paulo, SP: On line, 2004, p. 52-53.

CARDOSO, J.C.; ISRAEL, M. Levantamento de espécies da família Orchidaceae em Águas de Sta. Bárbara (SP) e seu cultivo. Horticultura Brasileira, Brasília, v. 23, n. 2, p.169-173, 2005.

DETTKE, G. A.; SANCHES-MARQUES, A. M. M.; MILANEZE-GUTIERRE, M. A. Anatomia vegetativa de três espécies de Maxillaria Ruiz et Pavón (Orchidaceae). Revista Brasileira de Biociências, Porto Alegre, v. 5, n. 1, p. 531-533, 2007.

EPSTEIN, E. Silicon. Annual Review in Plant Physiology and Plant Molecular Biology, v. 50, p. 641-664, 1999.

EPSTEIN, E. Silicon in plants, facts vs. Concepts. In: DATNOFF, L. E.; SNYDER, G. H; KORNDÖRFER, G. H. Silicon in agriculture. Studies in Plant Science. Amsterdam: Elsevier, 2001, v. 8 , p. $1-15$.

FARIA, R. T. et al. Produção de Orquídeas em Laboratório. 1. ed. Londrina, PR: Mecenas, 2012. $124 \mathrm{p}$.

FERREIRA, D. F. Sisvar: a computer statistical analysis system. Ciência \& Agrotecnologia, Lavras, v. 35 , n. 6 , p. 1039-1042, 2011.

HILDEBRAND, M. Biological processing of nanostructured silica in diatoms. Progress Organic Coatings, Amsterdam, v. 47, n. 3, p. 256-266, 2003.

JONES, L. H. P.; HANDRECK, K. A. Studies of silica in the oat plant. III. Uptake of silica from soils by plant. Plant and Soil, Dordrecht, v. 23, n. 1, p. 79 $-95,1965$.

MURASHIGE, T.; SKOOG, F. A revised medium for rapid growth and bio-assays with tobacco tissue cultures. Physiologia Plantarum, Copenhagen, v. 15, n. 1, p. 473-497, 1962.

SOARES, J. D. R. et al. G. Fontes de silício na micropropagação de orquídea do grupo Cattleya. Acta Scientiarum Agronomy, Maringá, v. 33, n. 3, p. 503-507, 2011.

VILLA, F. et al. Cloreto de potássio e fosfato de sódio na multiplicação in vitro de amoreira preta cv. tupy. Ciência \& Agrotecnologia, Lavras, v. 32, n. 1, p. $37-41,2008$.

ZANENGA-GODOY, R.; COSTA, C. G. Anatomia foliar de quatro espécies do gênero Cattleya Lindl. (Orchidaceae). Acta Botanica Brasilica, Belo Horizonte, v. 17, n. 1, p. 101-118, 2003.

TAIZ, L.; ZEIGER, E. Fisiologia Vegetal. 4. ed. Porto Alegre, RS: Artmed, 2009. 848 p.

ZANÃO JÚNIOR, L. A. et al. Rice resistence to brow spot mediated by silicon and its interaction whit manganese. Journal of Phytopathology, Berlin, v. 157, n. 2, p. 73-78, 2009.

YI-YONG, Z. et al. Involvement of plasma membrane $\mathrm{H}+$-ATPase in adaption of rice to ammonium nutrient. Rice Science, Hangzhou, v. 18, n. 4, p. 335-342, 2011. 